\title{
Models of Teaching English Using Curriculum 2013 for High School Students
}

\author{
Ngadiso $^{1}$, Teguh Sarosa ${ }^{1}$ \\ ${ }^{1}$ Universitas Sebelas Maret, JI. Ir. Sutami No. 36a, Surakarta, Indonesia \\ e-mail:ngadisodok@yahoo.com
}

\begin{abstract}
Based on Permendikbud 65/2013, the main activity of teaching and learning process using curriculum 13 uses models, methods, media, and learning resources which are appropriate with the characteristics of the students and the subject matter. The choice of approaches whether the teacher will use thematic, integrated thematic, scientific, inquiry, discovery, or project-based learning is based on the characteristics of competency and educational levels. The objectives of the research are: (1) to find out what approaches, methods, or techniques are used by the English teachers in teaching English using curriculum 13; and (2) to reveal why the English teachers use those approaches, methods, or techniques. The research is qualitative research. The data were collected using observation, questionnaire, and interview and analyzed using interactive model of analysis. The results of the research show that the English teachers used scientific approach, discovery learning, project-based learning, problem-based learning, role play, jigsaw, cooperative/collaborative learning, genrebased approach, communicative language teaching, contextual teaching and learning, community language learning, and task-based language learning. The approaches, methods, or techniques are based on the competences and indicators which are developed and the students' characteristics
\end{abstract}

Keywords: teaching English; curriculum 2013; qualitative research

\section{INTRODUCTION}

The current English teaching and learning process in SMA Surakarta has not simultaneously developed four English skills (listening, reading, speaking, and writing) because the English teachers still feel uncertain in implementing curriculum 13 in teaching English and developing four English skills (listening, reading, speaking, and writing). That is why it is necessary to find out approaches, methods, or techniques used by the English teachers of SMA Surakarta in implementing curriculum 13 in teaching English and developing four English skills (listening, reading, speaking, and writing) simultaneously.

The objectives of the research are: (1) to find out what approaches, methods, or techniques are used by the English teachers in teaching English using curriculum 13; and (2) to reveal why the English teachers use those approaches, methods, or techniques. 
The research findings can be used by English teachers of SMA Surakarta as one of stakeholders of higher education (Sebelas Maret University) to conduct English teaching and learning process which can develop the four English skills (listening, reading, speaking, and writing) simultaneously.

To support the implementation of the research, it is necessary to review curriculum 13. Based on Permendikbud No. 68/2013 [2], the rationale of curriculum 13 is as follows: (1) The graduates' competence standard is based on the need; (2) Content standard is based on graduates' competence standard through core competence which is free from subject matters; (3) All the subject matters must contribute to attitude, knowledge, and skill; (4) The subject matter is based on the competence which will be achieved; and (5) All subject matters are based on core competence.

The characteristics of curriculum 2013 according to Permendikbud No. 68/2013 [2] are as follows: (1) developing a balance between spiritual and social attitudes, curiosity, creativity, teamwork, and intellectual and psychomotor ability; (2) a school is a part of society which develops planned learning experience where the students will apply what is learned at school at their society and use society as the learning resources; (3) developing attitude, knowledge, and skill and apply them in any situations in schools and society; (4) giving adequate time to develop attitude, knowledge, and skill; (5) the competence is reflected in class' core competence which is further elaborated in subject's basic competence; (6) the class' core competence becomes organizing element of basic competence where all basic competences and subjects are developed to achieve the competence stated in core competence; and (7) basic competence is developed based on accumulating, reinforcing, and enriching principles among subjects and education levels (horizontal and vertical organizations).

SMA graduates' competences according to Permendikbud No. 54/2013 [3] are as follows: (1) attitude: having behavior which reflects attitude of people having faith, good ethic, knowledge, self-confidence, and responsibility in interacting effectively with natural and social environment; (2) knowledge: having factual, conceptual, procedural, and metacognitive knowledge; and (3) skill: having ability to behave effectively and creatively as the application of what has been learned at schools.

The changes of curriculum 13 in English subject according to Permendikbud No. 69/2013 [4] are as follows: (1) the materials taught are emphasized on English as a means of communication to convey ideas and knowledge; (2) the students are trained to read and comprehend texts and summarize the content using their own language; (3) the students are trained to construct systematic, logical, and effective English texts; (4) the students are familiarized with the texts' features so that their texts are not ambiguous; and (5) the students are trained to be able to express themselves and their knowledge spontaneously and confidently.

Based on Permendikbud 65/2013 [1], the main activity of teaching and learning process using curriculum 13 uses models, methods, media, and learning resources which are appropriate with the characteristics of the students and the subject matter. The choice of approaches whether the teacher will use thematic, integrated thematic, scientific, inquiry, discovery, or project-based learning is based on the characteristics of competency and educational levels.

The steps for strengthening process of curriculum 13 are as follows: (1) using scientific approach through observing, questioning, experimenting, associating, and 
communicating; (2) using science as learning movement of all subjects; (3) guiding the students to discover knowledge which is not being told (discovery learning); (4) emphasizing language competence as a means for communicating, getting knowledge, and thinking logically, systematically, and creatively; (5) measuring the students' thinking levels from low to high; (6) emphasizing on questions which support deep thinking (not solely retention); (7) measuring the students' working process, not only the results; and (8) using the students' learning portfolio.

Educational Ministry Regulation number 41 the year of 2007 [5] about the Process Standard states that every teacher should make Lesson Plans to foster the teaching and learning process to be interactive, inspiring, joyful, challenging, and motivating the students to participate actively, and giving enough opportunities to them to be innovative, creative and self-reliance according to their talents, motivations, and physical as well as psychological development. This activity is conducted systematically through exploration, elaboration, and conformation processes. By considering the nature of this teaching learning process, we agree to call this teaching method Inquiry-Based Instruction.

This inquiry-based teaching approach is based on three distinct phases of instruction: (1) exploration provides students with firsthand experiences with science phenomena; (2) concept introduction allows students to build science ideas through interaction with peers, texts, and teachers; and (3) concept application asks students to apply the science ideas to new situations or problems.

Project-based learning is teaching and learning process which involves individual's or group's projects conducted in a certain time. Project-based learning can be used to develop one English skill or more integrated English skills. The characteristics of project-based learning are: (1) student-centred; (2) communicative because the students should communicate to finish the project; (3) contextual; and (4) developing the students' soft skill.

Kumaravadivelu [6] states "project-based activities stress interactive language use that requires a synthesis of various language skills and various language components". Each English skill has some indicators to be developed in the teaching and learning process and should be measured at the end of the teaching and learning process (Joko Nurkamto, et al. [7]). Integrated teaching and learning process facilitates the students to practice four English skills (Brown, [8]).

Kumaravadivelu [6] states that the steps of integrated learning are as follows: (1) try to understand the teacher's directions, seek clarifications, and take notes (listening, speaking, and writing); (2) brainstorm, in pairs or in small groups, and decide to use library resources or the Internet to collect additional information (listening, speaking, reading, and writing); (3) engage in a decision-making process about how to use the collected information and proceed with the activity (listening, speaking, and reading); (4) carry out their plan of action (reading, writing, speaking, and listening); (5) use the notes taken during their group discussion, and present to class what they have accomplished (reading, speaking, and listening); and (6) finish the activity with a whole class discussion (listening and speaking).

Cooperative learning is an innovative method which can encourage the students to be active in working together to discuss and find the knowledge and skill by themselves. Cooperative learning, according to some experts, is defined as: a model of teaching that goes beyond helping students learn academic content and skills to address important social goals and objectives (Arends [9]); a diverse group of 
instructional methods in which small groups of students work together and help each other in completing academic tasks (Jacob [10]); an instructional use of small groups so that students work together to maximize their own and each other's learning and principles and techniques for helping students work together more effectively (Jacobs [11]); a teaching method where students work in small groups to help one another learn academic material, find answers to questions, rather than seeking answers from the instructor, and make sure that everyone in the group understands the concepts (Yamarik [12]); and a small group interactive instructional strategy that allows students to collaboratively work on meaningful tasks and to help themselves and others in the group to learn through social interaction (Johnson, et al. [13]).

Haycraft [14] states that to give more practices to your class, break them up into pairs or small groups. This encourages those who are shyer or reluctant to participate. Group work gives the students chances for greater independence. Because they are working together without the teacher controlling every movement, they take some of their own learning decisions, they decide what language to use to complete a certain task, and they can work without the pressure of the whole class listening to what they are doing (Harmer [15]).

The teacher is often described as being 'a guide on the side, not a sage on the stage' who undertakes the following (Jolliffe [16]): (1) Planning lessons that decides on (a) objectives; (b) size of groups; (c) how to group pupils; (d) group roles; (e) organization of the classroom; and (f) materials needed; (2) Explaining the task and the cooperative skill with criteria for the success of both; (3) Monitoring and intervening with groups where necessary; and (4) Evaluating the quality and quantity of achievement and ensuring that groups reflect on their achievement and effectiveness as a group and set goals for improvement.

One of the cooperative learning is jigsaw. The procedure of jigsaw is as follows: (1) Teacher chooses learning material that can be broken into parts; (2) The teacher gives out different assignment (part of the material) to different groups of students. Each group is assigned to read, discuss, and learn the material given to them; (3) After the study period, the teacher forms 'jigsaw learning' groups. Such groups contain a representative of every study group in the class. The member of each group then forms jigsaw learning groups with students from other groups. In this group everyone has learned or studied different segments or parts of the whole materials; (4) Members of the jigsaw group teach each other what they have learned; and (5) The teacher finally reconvenes the full class for reviewing the remaining questions to ensure accurate understanding.

\section{MATERIALS AND METHODS}

The research method used was qualitative research. According to Sutopo [17] qualitative method is a research method based on naturalist paradigm that has some characteristics. First, data are collected from natural setting. Second, data are in descriptive form. Third, it is concerned with the process. It can interpret behavior, activity, procedure, and interaction. Fourth, the data are analyzed inductively. Fifth, the inquiry is value-bound. The method is selected because this research is based on natural setting or in entity context. Here, natural setting means the condition of the 
research subject is directed to the natural or real condition of the field. The setting of the research is the teaching and learning process in SMAs Surakarta.

The data were collected using observation, questionnaire, and interview to find out: (1) the approaches, methods, or techniques used by the English teachers of SMA Surakarta in teaching English using curriculum 13; and (2) why the English teachers use those approaches, methods, or techniques. To check the validity of the data, triangulation was used in this research. The collected data were analyzed using interactive model of analysis as follows: (1) Data reduction (selecting, focusing, simplifying, ... raw data); (2) Data display (an organized assembly of information that permits conclusion drawing and action taking); and (3) Conclusion drawing/verification (what things mean, noting regularities, pattern, explanation, possible configuration, causal flows, and proposition) (Miles and Huberman [18]).

\section{RESULTS AND DISCUSSION}

The research findings show that:

1. In teaching English, the English teachers of SMA Surakarta used:

a. Scientific approach

b. Discovery learning

c. Project-based learning

d. Problem-based learning

e. Role play

f. Jigsaw

g. Cooperative/collaborative learning

h. Genre-based Approach

i. Communicative Language Teaching

j. Contextual teaching and learning

k. Community language learning

1. Task-based language learning

2. The reasons why the English teachers used those approaches, methods, or techniques are as follows:

\begin{tabular}{|lll|}
\hline No. & $\begin{array}{c}\text { Approaches, methods, } \\
\text { or techniques }\end{array}$ & \multicolumn{1}{c|}{ The reasons } \\
\hline a. & Scientific approach & $\begin{array}{l}\text { 1. It is required by curriculum 13 to use } \\
\text { scientific approach }\end{array}$ \\
& $\begin{array}{l}\text { 2. It is appropriate to start teaching by } \\
\text { asking the students to observe (for } \\
\end{array}$ & example to watch videos or to listen to \\
& the audio), followed by experimenting, \\
& associating, and reporting/ \\
& communicating \\
& 3. To train integrated English skills (at least \\
& two English skills) \\
\hline
\end{tabular}




\begin{tabular}{|c|c|c|}
\hline b. & Discovery learning & $\begin{array}{l}\text { 1. The English teachers usually give } \\
\text { examples and guide the students to find } \\
\text { the new concept by themselves (eg. the } \\
\text { students are supposed to find out the } \\
\text { sentence patterns based on the data } \\
\text { exposed to them) }\end{array}$ \\
\hline c. & Project-based learning & $\begin{array}{l}\text { 1. It is challenging for the students (eg. for } \\
\text { developing writing and speaking skills } \\
\text { by making advertisements) } \\
\text { 2. To develop the students' writing skill by } \\
\text { doing the project }\end{array}$ \\
\hline d. & Problem-based learning & $\begin{array}{l}\text { 1. To develop the students' speaking skill } \\
\text { by conducting group discussion } \\
\text { 2. It is appropriate in giving suggestions } \\
\text { 3. To develop the students' writing or } \\
\text { speaking skills by discussing an issue } \\
\text { and finding out the solution }\end{array}$ \\
\hline e. & Role play & $\begin{array}{l}\text { 1. To teach speaking, especially expression } \\
\text { 2. To develop the students' speaking skill } \\
\text { (eg. narrative oral text) } \\
\text { 3. To develop the students' speaking skill }\end{array}$ \\
\hline f. & Jigsaw & $\begin{array}{l}\text { 1. To teach reading in order that the } \\
\text { reading class is not boring }\end{array}$ \\
\hline g. & $\begin{array}{l}\text { Cooperative/collaborative } \\
\text { learning }\end{array}$ & $\begin{array}{l}\text { 1. It is effective to balance the } \\
\text { performance of good and bad students } \\
\text { 2. To train teamwork, to write together, and } \\
\text { speaking practice }\end{array}$ \\
\hline h. & Genre-based Approach & $\begin{array}{l}\text { 1. To develop the students' reading skill } \\
\text { 2. To integrate all English skills in teaching } \\
\text { English texts and it is effective to teach } \\
\text { English texts } \\
\text { 3. To develop listening, reading, writing, } \\
\text { and speaking skills }\end{array}$ \\
\hline i. & $\begin{array}{l}\text { Communicative } \\
\text { Language Teaching }\end{array}$ & $\begin{array}{l}\text { 1. It is good for improving the students' } \\
\text { communicative competence } \\
\text { 2. To develop all English skills, especially } \\
\text { to develop direct communicative } \\
\text { competence either speaking or writing }\end{array}$ \\
\hline $\mathrm{j}$. & $\begin{array}{l}\text { Contextual teaching and } \\
\text { learning }\end{array}$ & $\begin{array}{l}\text { 1. It is used for teaching writing news item } \\
\text { to practice writing in context }\end{array}$ \\
\hline $\mathrm{k}$. & $\begin{array}{l}\text { Community language } \\
\text { learning }\end{array}$ & $\begin{array}{l}\text { 1. To develop the students' speaking skill } \\
\text { in English clubs } \\
\text { 2. It is used for post-school activity to give } \\
\text { relaxing atmosphere } \\
\text { 3. To develop the students' speaking skill } \\
\text { in extracurricular English club }\end{array}$ \\
\hline 1. & $\begin{array}{l}\text { Task-based language } \\
\text { learning }\end{array}$ & $\begin{array}{l}\text { 1. To measure the students' comprehension } \\
\text { in two different basic competences }\end{array}$ \\
\hline
\end{tabular}




\section{CONCLUSIONS}

The conclusions which can be drawn from the research findings are:

1. In teaching English, the English teachers of SMA Surakarta used 12 approaches, methods, or techniques (Scientific approach, Discovery learning, Project-based learning, Problem-based learning, Role play, Jigsaw, Cooperative/collaborative learning, Genre-based Approach, Communicative Language Teaching, Contextual teaching and learning, Community language learning, and Task-based language learning)

2. The English teachers used those approaches, methods, or techniques because they wanted to make the students active (student-centred learning), to develop four English skills, and to make the teaching and learning process more interesting.

\section{ACKNOWLEDGEMENTS}

The paper is written based on the research which has been conducted. The paper has not been published in the national and international journals and proceedings of national and international seminars.

\section{REFERENCES}

[1] Permendikbud No. 65/2013

[2] Permendikbud No. 68/2013

[3] Permendikbud No. 54/2013

[4] Permendikbud No. 69/2013

[5] Educational Ministry Regulation number 41/2007

[6] Kumaravadivelu, B. 2003. “Beyond Methods: Macrostrategies for Language Teaching." London: Yale University Press.

[7] Joko Nurkamto, et al. 2012. "Modul Model-Model, Media, dan Evaluasi Pembelajaran Bahasa Inggris UNS 2012." Surakarta: UNS Press.

[8] Brown, H. D. 2000. "Teaching by Principles: An Interactive Approach to Language Pedagogy." Pearson Education Inc.

[9] Arends, R.I. 1989. “Learning to Teach.” New York: McGraw-Hill Book Company.

[10] Jacob, E. 1999. “Cooperative Learning in Context; An Educational Innovation in Everyday Classrooms". New York: State University of New York Press.

[11] Jacobs, G. 2004. “Cooperative Learning: Theory, Principles, and Techniques," JF New Paradigm of Education.

[12] Yamarik, S. 2005. "Does cooperative learning improve student's outcomes?" California: California State University.

[13] Johnson, D.W., et al. 1994."The New Circles of Learning: Cooperation in the Classroom and School." Virginia: Assoc. for Supervision and Curriculum Development.

[14] Haycraft, John. 1978. “An Introduction to English Language Teaching.” Longman Group Ltd.

[15]Harmer, Jeremy. 1998. "How to Teach English." England: Adison Wesley Longman Limited, Essex.

[16] Jolliffe, W. 2007. "Cooperative Learning in the Classroom; Putting it into Practice." London: Paul Chapman Publishing

[17] Heribertus, Sutopo. 1998. “Metodologi Penelitian Kualitatif: Dasar Teori dan Terapannya dalam Penelitian." Surakarta: UNS Press.

[18] Miles, M. B \& Huberman, A. M. 1984. "Qualitative Data Analysis: A Source Book of A New Method.” Beverly Hills: Sage Publications 